From a practical point of view cytology is a convenient screening method for detecting possible polyomavirus excretors. Electron microscopy is more sensitive but less practical for large surveys. Virus isolation presents the difficulty of maintaining large numbers of cultures for long periods of incubation. Cytology can detect strongly positive excretors such as case 108, and it is from such patients that virus is most readily isolated. In large surveys it may be appropriate to use cytology as a preliminary screening procedure with electron microscopy and virus isolation for confirmation of virus excretion.

The only human disease with which polyomaviruses have so far been associated is the rare neurological disorder progressive multifocal leucoencephalopathy (P.M.L.). Patients with this disease are often found to have immunological defects, and a single occurrence of P.M.L. has been described in a patient 17 months after renal transplantation (Manz et al., 1971). No case of P.M.L. occurred in our series of patients. They will continue under observation because of the possibility of P.M.L. developing and because of the oncogenic potential of this group of viruses.
We are grateful to Professor W. S. Peart and Dr. B. Hulme for permission to investigate this group of patients, and to $\mathrm{Mr}$. A. A. Porter for help with the electron microscopy.

\section{References}

Coleman, D. V., Field, A. M., Gardner, S. D., Porter, K. A., and Starzl, T. E. (1973). Transplantation Proceedings, 5, 95.

Gardner, S. D., Field, A. M., Coleman, D. V., and Hulme, B. (1971). Lancet, 1, 1253.

Hulme, B., Snell, M. E., Kenyon, J. R., Owen, K., and Peart, W. S. (1972). British Medical fournal, 4, 139

Lecatsas, G., Prozesky, O. W., Van Wyk, J., and Els, H. J. (1973). Nature, 241, 343.

Manz, H. J., Dinsdale, H. B., and Morrin, P. A. F. (1971). Annals of Internal Medicine, 75, 77.

Padgett, B. L., Walker, D. L., ZuRhein, G. M., and Eckroad, R. J. (1971). Lancet, 1, 1257.

Pletka, P., et al. (1969). Lancet, 4, 1.

Weiner, L. P., et al. (1972). New England fournal of Medicine, 286, 385.

\title{
Vasopressin Analogue DDAVP in Diabetes Insipidus: Clinical and Laboratory Studies
}

\author{
C. R. W. EDWARDS, M. J. KITAU, T. CHARD, G. M. BESSER
}

British Medical fournal, 1973, 3, 375-378

\begin{abstract}
Summary
In seven patients with cranial diabetes insipidus an analogue of vasopressin, DDAVP, produced an antidiuresis lasting up to 20 hours after a single intranasal dose. Lysine vasopressin (LVP) in the same dose produced a less potent antidiuresis which lasted for only three to four hours. The plasma half life of DDAVP was 7.8 and $75.5 \mathrm{~min}$ for the fast and slow phases, compared with 2.5 and $14.5 \mathrm{~min}$ for LVP. Radioiodine-labelled DDAVP was not destroyed by incubation with late pregnancy plasma, which contains an enzyme that inactivates vasopressin. The slow metabolic clearance of DDAVP, its absorption through the nasal mucosa, and its lack of side effects make this the ideal drug for the treatment of vasopressin-sensitive diabetes insipidus. Patients usually require 10 to $20 \mu \mathrm{g}$ DDAVP given intranasally twice daily for good clinical control of their diabetes insipidus.
\end{abstract}

\section{Introduction}

Though many different forms of therapy have been used in the treatment of diabetes insipidus (D.I.), until recently injections of Pitressin Tannate (vasopressin tannate) in oil have been the only satisfactory method for the treatment of severe cases. Pitressin, however, is an impure preparation which includes several peptides other than vasopressin, including oxytocin,

\footnotetext{
Medical Professorial Unit and Department of Chemical Pathology, St. Bartholomew's Hospital, London EC1A 7BE C. R. W. EDWARDS, M.B., M.R.C.P., Lecturer in Medicine M. J. KITAU, A.I.M.L.T., Senior Technician

T. CHARD, M.D., M.R.c.o.G., Senior Lecturer in Reproductive Physiology G. M. BESSER, M.D., F.R.C.P., Senior Lecturer in Endocrinology
}

neurophysin (Martin, 1971), prolactin, and a corticotrophin-like peptide (Scott et al., 1972). Martin (1971) showed that patients treated with Pitressin may produce high titres of antibodies against neurophysin. Furthermore, patients often find the injections difficult to administer and unpleasant to receive.

A number of drugs unrelated to vasopressin have been found to be useful in the management of diabetes insipidus, including diuretics (Crawford and Kennedy, 1959), chlorpropamide (Arduino et al., 1966), carbamazepine (Braunhofer and Zicha, 1966), and clofibrate (De Gennes et al., 1970). The mechanism of their action is not well understood, but chlorpropamide appears to act by increasing renal responsiveness to endogenous vasopressin (Berndt et al., 1970; Miller and Moses, 1970). Side effects such as hypokalaemia with diuretics and hypoglycaemia with chlorpropamide have limited their use, especially in children. Furthermore, for effective chlorpropamide therapy some functioning posterior pituitary must remain, and in many patients the "Antabuse"-like actions of chlorpropamide are unacceptable.

$\mathrm{CH}_{2}-\mathrm{CO}-\mathrm{Tyr}-\mathrm{Phe}-\mathrm{Cln}-\mathrm{Asn}-\mathrm{Cys}-$ Pro-D-Arg-Cly $\mathrm{NH}_{2}$
$\mathrm{CH}_{2}-\mathrm{s}-\mathrm{S}-\mathrm{I}$

FIG. 1-Amino-acid sequence of (1-desamino-8-D-arginine) vasopressin, DDAVP. Also known as (1-beta-mercaptoproprionic acid -8-D-arginine) vasopressin.

Synthetic lysine vasopressin (LVP) given as a nasal spray has advantages over pituitary snuff in that it does not result in local hypersensitivity phenomena (Pepys et al., 1965) or pulmonary complications (Mahon et al., 1967). Its effects, however, are too short-lasting to be useful in patients with severe diabetes insipidus. An analogue of vasopressin, 1-desamino-8-D-arginine vasopressin (DDAVP) (fig. 1), has greater antidiuretic potency, longer duration of action, and much less pressor effect when compared with other commercially available preparations of vasopressin. Its synthesis and chemical properties were described by Zaoral et al. (1967) and a study of its pharmacological properties with a preliminary report of its clinical application by Vavra et al. (1968). It has been suggested that the prolonged 
length of action of DDAVP is due to the absence of the amino group on the $\mathrm{N}$-terminal hemicystine, producing resistance to aminopeptidase enzymes, and the diminished pressor activity to the replacement of $L$-arginine by $D$-arginine. Until recently the limited availability of DDAVP has prevented further clinical evaluation. This paper reports studies on the in-vivo and invitro destruction of this analogue.

\section{Patients and Methods}

\section{IN-VIVO STUDIES}

DDAVP was given either intranasally or intravenously to seven patients with cranial diabetes insipidus and to two patients with nephrogenic diabetes insipidus. The diagnosis was made on the basis of the plasma and urinary osmolalities and urinary immunoreactive vasopressin levels during an eight-hour waterdeprivation test (Besser, 1972; Edwards et al., 1972 a). The results of these diagnostic procedures are given in table I. All patients concentrated their urine normally in response to exogenous vasopressin.

TABLE I-Results of Diagnostic Procedures in Patients studied

\begin{tabular}{c|c|c|c|c|c}
\hline $\begin{array}{c}\text { Case } \\
\text { No. }\end{array}$ & $\begin{array}{c}\text { Age } \\
\text { in } \\
\text { Years }\end{array}$ & Sex & Associated Diagnosis & \multicolumn{2}{|c|}{\begin{tabular}{c} 
After 8 Hours of Water Deprivation: \\
\cline { 3 - 5 }
\end{tabular}} \\
\hline
\end{tabular}

Cranial Diabetes Insipidus

\begin{tabular}{|c|c|c|c|c|c|}
\hline \multicolumn{6}{|c|}{ 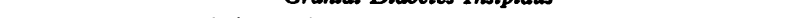 } \\
\hline $\begin{array}{l}1 \\
2 \\
3\end{array}$ & $\begin{array}{r}3 \\
19 \\
46 \\
63\end{array}$ & $\begin{array}{l}\mathbf{F} . \\
\mathbf{M} . \\
\mathbf{F} \\
\mathbf{M}\end{array}$ & $\begin{array}{l}\text { Histiocytosis } \\
\text { Diabetes mellitus } \\
\text { Histiocytosis } \\
\text { Acromegaly, D.I., }\end{array}$ & $\begin{array}{l}58^{*} \\
99^{*} \\
94 \dagger \\
478\end{array}$ & $\begin{array}{l}303 \\
313 \\
319 \\
302\end{array}$ \\
\hline 5 & 32 & F. & $\begin{array}{l}\text { posthypophysectomy } \\
\text { Acromegaly, D.I., } \\
\text { posthypophysectomy }\end{array}$ & 479 & 295 \\
\hline 6 & $\begin{array}{l}\mathbf{5 7} \\
\mathbf{5 1}\end{array}$ & $\begin{array}{l}\mathbf{F} \text {. } \\
\text { F. }\end{array}$ & $\begin{array}{l}\text { Pituitary tumour } \\
\text { Idiopathic }\end{array}$ & $\begin{array}{l}270 \\
138\end{array}$ & $\begin{array}{l}316 \\
308\end{array}$ \\
\hline \multicolumn{6}{|c|}{ Nephrogenic Diabetes Insipidus } \\
\hline $\begin{array}{l}8 \\
9\end{array}$ & $\begin{array}{r}2 \\
18\end{array}$ & $\begin{array}{l}\text { M. } \\
\text { F. }\end{array}$ & $\begin{array}{l}\text { Primary } \\
\text { Chronic renal failure of } \\
\text { unknown aetiology }\end{array}$ & $\begin{array}{l}129 \neq \\
169\end{array}$ & $\begin{array}{l}\mathbf{3 0 8} \\
\mathbf{3 0 4}\end{array}$ \\
\hline
\end{tabular}

* Test stopped after four hours.

Test stopped after six hours.
\$ Test stopped after five hours.

The patients with cranial diabetes insipidus had previously been treated with either Pitressin Tannate in oil or chlorpropamide or LVP nasal spray. Pitressin and chlorpropamide were stopped at least four days before and LVP on the day before giving DDAVP. The two patients with nephrogenic diabetes insipidus were studied while on diuretic therapy. One patient (case 2), with both diabetes insipidus and diabetes mellitus, had impaired renal function with severe bilateral hydronephrosis.

Before administering DDAVP the patients were given a 1-1. oral water load and the urine flow rate was subsequently stabilized by giving oral fluids in a volume equivalent to that of the urine passed. After stabilization DDAVP was given either intravenously ( 2 or $3 \mu \mathrm{g})$ or intranasally $(20 \mu \mathrm{g})$. In three patients and one normal volunteer subject given intravenous DDAVP blood samples were taken into cooled heparinized syringes at $2,5,10,20,30$, and $45 \mathrm{~min}$ and then separated at $4^{\circ} \mathrm{C}$. The plasma was acidified to pH 1-2 with $N$ hydrochloric acid before storage at minus $20^{\circ} \mathrm{C}$. The DDAVP levels were measured by radioimmunoassay using an antiserum produced by immunization with arginine vasopressin (AVP) and LVP and specific for the amino-acid sequence phenylalanine 3 to proline 7 (Edwards, 1970; Edwards et al., 1970; Edwards et al., 1972 b).

Some patients were also given LVP intravenously $(2 \mu \mathrm{g})$ or intranasally $(20 \mu \mathrm{g})$. After intravenous administration blood samples were taken as above. The same antiserum was used for the LVP assay as for the DDAVP. In the DDAVP assay ${ }^{125}$ IDDAVP was used as labelled hormone and ${ }^{125} \mathrm{I}-\mathrm{AVP}$ for the LVP assay. After giving DDAVP or LVP urine samples were collected every two hours and their osmolality was measured with an Advance osmometer.

The half times for the two phases of the experimental disappearance curves from blood were calculated from a semilogarithmic plot of plasma concentration against time and were obtained by the method of least squares (Snedecor, 1956).

\section{IN-VITRO STUDIES}

The destruction of ${ }^{125} \mathrm{I}$-labelled DDAVP and AVP by the proteolytic enzymes present in late pregnancy plasma was assessed by incubating $0.75 \mathrm{ml}$ of a solution containing $80 \mu \mathrm{g} / \mathrm{ml}$ ${ }^{125}$ I-AVP or DDAVP with $0.75 \mathrm{ml}$ of late pregnancy plasma at $37^{\circ} \mathrm{C}$. Two $100-\mu \mathrm{l}$ aliquots were removed at $0,60,120$, and 180 min, diluted $1 / 50$, and kept at $4^{\circ} \mathrm{C}$. The immunoreactivity of the labelled hormone was measured by incubation for one hour with the same antiserum used for the plasma assays. The antibodybound and free hormones were then separated using ammonium sulphate precipitation (Edwards et al., 1972 b).

\section{Results}

\section{IN-VIVO STUDIES}

$D D A V P$. - The urine flow rates and osmolalities after DDAVP are shown in tables II and III. In each of the seven patients with cranial diabetes insipidus given DDAVP intranasally (table II) there was a marked antidiuresis. In the 3-year-old girl with histiocytosis given $2.5 \mu \mathrm{g}$ DDAVP intranasally (case 1) the antidiuresis lasted for eight hours, but in the other six patients given $20 \mu \mathrm{g}$ intranasally a much more prolonged antidiuresis was observed. In no patient had the urine flow rate returned to pretreatment levels by 10 hours, and in three patients followed for 20 hours DDAVP was still effective. A similar result was obtained with $2 \mu \mathrm{g}$ DDAVP intravenously. In the patients with cranial diabetes insipidus the mean maximum urinary osmolality

TABLE III-Urine Flow Rates and Osmolalities after DDAVP in Patients with Nephrogenic Diabetes Insipidus

\begin{tabular}{|c|c|c|c|c|c|c|c|c|c|c|c|}
\hline \multirow{3}{*}{$\begin{array}{l}\text { Case } \\
\text { No. }\end{array}$} & \multirow{3}{*}{$\begin{array}{c}\text { Intravenous } \\
\text { Dose } \\
\text { DDAVP } \\
(\mu \mathrm{g})\end{array}$} & \multicolumn{5}{|c|}{ Flow Rate (ml/min) } & \multicolumn{5}{|c|}{ Osmolality (mOsm/kg) } \\
\hline & & \multirow{2}{*}{$\begin{array}{c}\text { Before } \\
\text { DDAVP }\end{array}$} & \multicolumn{4}{|c|}{$\begin{array}{l}\text { Minutes after } \\
\text { DDAVP }\end{array}$} & \multirow{2}{*}{$\begin{array}{c}\text { Before } \\
\text { DDAVP }\end{array}$} & \multicolumn{4}{|c|}{$\begin{array}{l}\text { Minutes after } \\
\text { DDAVP }\end{array}$} \\
\hline & & & $0-30$ & -60 & -90 & -120 & & $0-30$ & -60 & -90 & -120 \\
\hline $\begin{array}{l}8 \\
9\end{array}$ & $\begin{array}{l}2 \\
2\end{array}$ & $\begin{array}{l}4 \cdot 1 \\
3 \cdot 1\end{array}$ & $\begin{array}{l}4.5 \\
1.9\end{array}$ & \begin{tabular}{|l|}
$5 \cdot 4$ \\
$2 \cdot 1$
\end{tabular} & $\begin{array}{l}6 \cdot 4 \\
2 \cdot 3\end{array}$ & \begin{tabular}{|l|}
$7 \cdot 0$ \\
$2 \cdot 2$
\end{tabular} & $\begin{array}{r}70 \\
138\end{array}$ & $\begin{array}{r}64 \\
194\end{array}$ & $\begin{array}{r}64 \\
239\end{array}$ & $\begin{array}{r}67 \\
241\end{array}$ & $\begin{array}{r}72 \\
240\end{array}$ \\
\hline
\end{tabular}

TABLB II-Urine Flow Rates and Osmolalities after DDAVP in Patients with Cranial Diabetes Insipidus

\begin{tabular}{|c|c|c|c|c|c|c|c|c|c|c|c|c|c|c|c|c|c|c|}
\hline & \multirow{3}{*}{ Caise No. } & \multirow{3}{*}{$\begin{array}{c}\text { Intranasal } \\
\text { Dose DDAVP } \\
(\mu \mathrm{g})\end{array}$} & \multicolumn{8}{|c|}{ Flow Rate (ml/min) } & \multicolumn{8}{|c|}{ Osmolality (mOsm/kg) } \\
\hline & & & \multirow[b]{2}{*}{ Before DDAVP } & \multicolumn{7}{|c|}{ Hours after DDAVP } & \multirow[b]{2}{*}{ Before } & \multicolumn{7}{|c|}{ Hours after DDAVP } \\
\hline & & & & $0-2$ & -4 & -6 & -8 & -10 & -12 & -20 & & $0-2$ & -4 & -6 & -8 & -10 & -12 & -20 \\
\hline 0 & $\begin{array}{l}\ldots \\
\ddot{ } \\
\ddot{ } \\
\ddot{ } \\
\therefore\end{array}$ & $\begin{array}{l}2.5 \\
20 \\
20 \\
20 \\
20 \\
20 \\
20\end{array}$ & $\begin{array}{r}2.7 \\
3.3 \\
9.2 \\
9.9 \\
8.9 \\
4.8 \\
12.3\end{array}$ & $\begin{array}{l}0.4 \\
2.5 \\
1.5 \\
1.9 \\
1.5 \\
1.0 \\
2.0\end{array}$ & $\begin{array}{l}0.3 \\
1.1 \\
0.3 \\
0.6 \\
0.9 \\
0.4 \\
0.5\end{array}$ & $\begin{array}{l}0.5 \\
0.7 \\
0.4 \\
0.8 \\
0.7 \\
0.5 \\
1.0\end{array}$ & $\begin{array}{l}2.1 \\
0.9 \\
1.0 \\
0.5 \\
0.4 \\
0.4 \\
0.9\end{array}$ & $\begin{array}{l}\overline{-} \\
2.8 \\
0.3 \\
0.5 \\
0.4 \\
2.3\end{array}$ & $\begin{array}{l}\overline{-} \\
\frac{3.9}{1.9} \\
0.4\end{array}$ & $\begin{array}{l}\overline{\bar{Z}} \\
\frac{8 \cdot 2}{4 \cdot 5} \\
1 \cdot 0\end{array}$ & $\begin{array}{r}50 \\
85 \\
395 \\
113 \\
44 \\
73 \\
56\end{array}$ & $\begin{array}{l}363 \\
197 \\
693 \\
347 \\
203 \\
372 \\
186\end{array}$ & $\begin{array}{l}544 \\
313 \\
769 \\
522 \\
273 \\
708 \\
520\end{array}$ & $\begin{array}{l}450 \\
385 \\
444 \\
575 \\
408 \\
721 \\
519\end{array}$ & $\begin{array}{l}153 \\
422 \\
248 \\
655 \\
503 \\
791 \\
380\end{array}$ & $\begin{array}{l}\overline{-} \\
\overline{183} \\
700 \\
352 \\
814 \\
168\end{array}$ & $\begin{array}{l}\overline{\overline{1}} \\
\frac{165}{185} \\
786\end{array}$ & $\begin{array}{r}\bar{二} \\
\overline{83} \\
543\end{array}$ \\
\hline
\end{tabular}


after DDAVP was $610 \mathrm{mOsm} / \mathrm{kg}$. In the boy with primary nephrogenic diabetes insipidus (case 8, table III) intravenous DDAVP $2 \mu \mathrm{g}$ produced no antidiuresis, and an impaired response was seen in the patient with nephrogenic diabetes insipidus and renal failure (case 9). No side effects were observed after intranasal or intravenous DDAVP.

LVP.-An antidiuresis of lower amplitude and duration followed the administration of LVP. The mean maximum urine osmolality. was $307 \mathrm{mOsm} / \mathrm{kg}$, and urine flow rates returned to pretreatment levels within three hours after $2 \mu \mathrm{g}$ intravenously and four hours after $20 \mu \mathrm{g}$ intranasally. Unlike DDAVP intravenous LVP produced pallor and colicky abdominal pain. Intranasal LVP had been found to produce nasal irritation in four out of six patients with cranial diabetes insipidus.

Disappearance Rates. - The disappearance of immunoreactive DDAVP and LVP after a single intravenous injection followed a biexponential pattern (fig. 2) when plotted semilogarithmically against time. The mean half life of DDAVP was $7 \cdot 8 \mathrm{~min}$ for the first and $75.5 \mathrm{~min}$ for the second exponential (table IV). A much shorter half life was found for LVP (2.5 min for the first and $14.5 \mathrm{~min}$ for the second exponential).

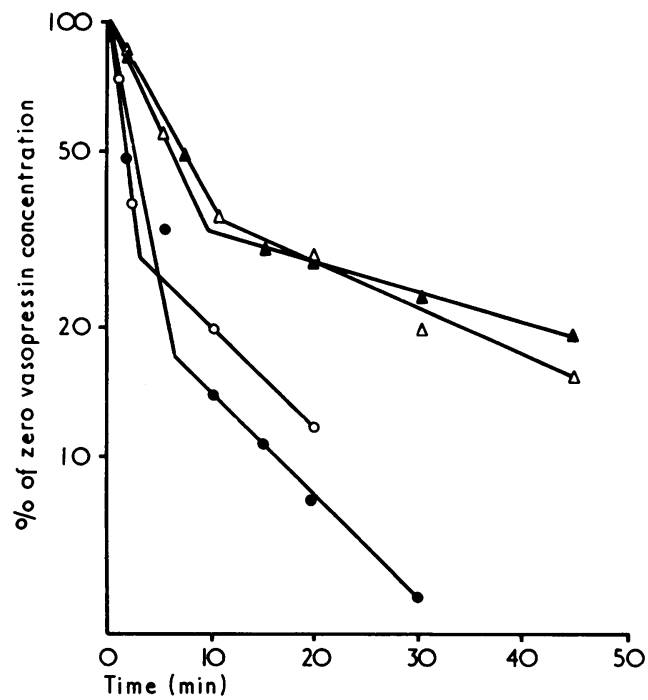

FIG. 2-Disappearance of immunoreactive DDAVP $\left(\Delta-\Delta, \Delta \frac{\Delta}{-}\right)$ and LVP $(0-0,0-0)$

from plasma after single intravenous injections.

TABLE IV-Half Life of DDAVP and LVP after Single Intravenous Injection

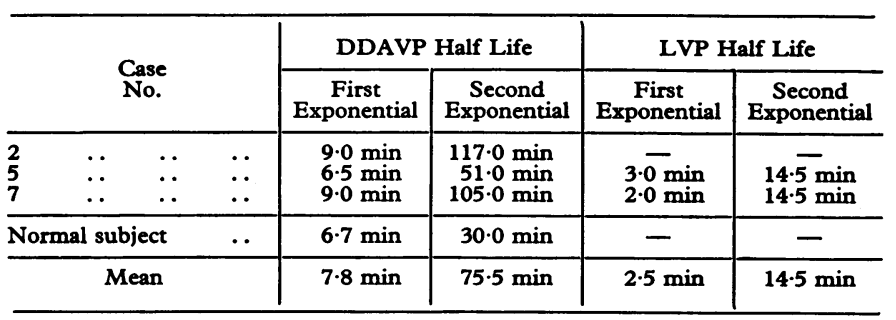

\section{IN-VITRO STUDIES}

Incubation of ${ }^{125}$ I-labelled AVP with late pregnancy plasma progressively destroyed the ability of the labelled hormone to bind to antibody (fig. 3). Iodinated DDAVP was unaffected during this period of incubation.

\section{Discussion}

These results confirm the value of DDAVP in the treatment of diabetes insipidus. After intranasal or intravenous administration it produces a prolonged antidiuresis without side effects. Each of the patients with cranial diabetes insipidus was well controlled

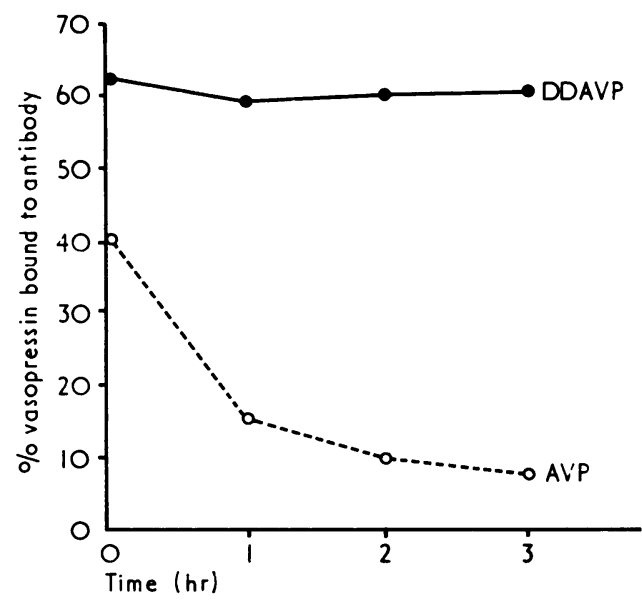

FIG. 3-Destruction of immunoreactivity of 12'Ilabelled DDAVP and AVP by incubation with late pregnancy plasma.

on DDAVP 10 to $20 \mu \mathrm{g}$ intranasally twice daily. In all we have now treated 14 patients with this vasopressin analogue and it has been well tolerated, reliable, and without side effects.

it. Zaoral and Sorm (1966): and Zaoral et al. (1967) showed that the substitution of $D$-arginine for $L$-arginine in position $8 \mathrm{de}-$ creased the pressor effect of vasopressin. Also the removal of the amino group of the hemicystine in position 1 enhanced the antidiuretic activity. It was suggested that the absence of the amino group protected the molecule against breakdown by aminopeptidase enzymes. The absence of the $\mathrm{N}$-terminal amino group of the potent oxytocin analogue, desamino-oxytocin, has been shown to prevent its inactivation by late pregnancy serum (Golubow et al., 1963). The experiments presented here with labelled AVP and DDAVP suggest that this is also true for DDAVP. Nevertheless, the importance of this method of inactivation in the intact subject is not known. Walter and Bowman (1973) suggested that the inactivation of vasopressin occurs by release of the C-terminal glycinamide moiety. In their experiments using infusions of (9-14 $\mathrm{C}$-glycinamide)-vasopressin into an isolated perfused rat kidney large amounts of a ${ }^{14} \mathrm{C}$ glycinamide fragment were excreted in the urine. They proposed a distal renal tubular location for the inactivating enzyme and that inactivation was not related to the interaction between the hormone and the receptor but was important for the clearance of vasopressin from the systemic circulation. The presence of the D-isomer in position 8 may protect DDAVP from this inactivating enzyme. This could explain the long half life of 7.8 min for DDAVP. By comparison LVP had a much shorter half life $(2.5 \mathrm{~min})$, similar to that found by Johnston (1972) in sheep (3.2 min) and by Roth et al. (1968) for AVP in man (3 $\mathrm{min})$.

The slow metabolic clearance of DDAVP, its absorption through the nasal mucosa, and its lack of side effects make this the ideal drug for the treatment of vasopressin-sensitive diabetes insipidus.

We thank Dr. J. Mulder, research director, Ferring, A.B., Malmo, Sweden, for the supply of DDAVP, and Dr. E. R. Evans, Sandoz Products Ltd., for the LVP. C.R.W.E. is in receipt of the Peel Medical Research Trust Travelling Fellowship and a Wellcome Travel Grant.

Requests for reprints should be sent to Dr. G. M. Besser.

\section{References}

Arduino, F., Ferraz, F. P. J., and Rodrigues, J. (1966). Fournal of Clinical Endocrinology and Metabolism, 26, 1325.

Berndt, W. O., Miller, M., Kettyle, W. M., and Valtin, H. (1970). Endocrinology, 86, 1028.

Besser, G. M. (1972). In Medicine, No. 2. Endocrine Diseases, ed. R. Bayliss and $\mathbf{R}$. Hall. London, Medical Education (International) Braunhofer, J., and Zicha, L. (1966). Medizinische Welt, 36, 1875. 
Crawford, J. D., and Kennedy, G. C. (1959). Nature, 183, 891. d'Endocrinologie, 31, 300 .

Edwards, C. R. W. (1970). Proceedings of the Royal Society of Medicine, 64, 32.

Edwards, C. R. W., Chard, T., Kitau, M. J., and Forsling, M. L. (1970). Fournal of Endocrinology, 48, xi.

Edwards, C. R. W., Kitau, M. J., Martin, M. J., and Chard, T. (1972 a). Excerpta Medica International Congress Series, No. 256.

Edwards, C. R. W., Chard, T., Kitau, M. J., Forsling, M. L., and Landon, J. (1972 b). Fournal of Endocrinology, 52, 279.

Golubow, J., Chan, W. Y., and Du Vigneaud, V. (1963). Proceedings of the Society for Experimental Biology and Medicine, 113, 113.

Johnston, C. I. (1972). Fournal of Endocrinology, 52, 69.

Mahon, W. E., Scott, D. J., Ansell, G., Manson, G. L., and Fraser, R. (1967). Thorax, 22, 13 .
Martin, M. J. (1971). Fournal of Endocrinology, 49, 553.

Miller, M., and Moses, A. M. (1970). Endocrinology, 86, 1024

Pepys, J., Jenkins, P. A., Lachman, P. J., and Mahon, W. E. (1965). Fournal of Endocrinology, 33, viii.

Roth, J., Klein, L. A., and Gorden, P. (1968). Excerpta Medica International Congress Series, No. 157.

Scott, A. P., Rees, L. H., Ratcliffe, J. G., and Besser, G. M. (1972). Fournal of Endocrinology, 53, xxxviii.

Snedecor, G. W. (1956). Statistical Methods, 5th edn. Iowa State University Press.

Vavra, I., et al. (1968). Lancet, 1, 948.

Walter, R., and Bowman, R. H. (1973). Endocrinology, 92, 189.

Zaoral, M., and Sorm, F. (1966). Collection of Czechoslovak Chemical Communications, 31, 310 .

Zaoral, M., Kolc, J., and Sorm, F. (1967). Collection of Czechoslovak Chemical Communications, 32, 1250.

\title{
Immediate Sterility after Vasectomy
}

\author{
D. URQUHART-HAY
}

British Medical fournal, 1973, 3, 378-379

\section{Summary}

A 2.5-ml injection of $1 / 1,000$ solution of euflavine given down each vas during vasectomy for sterilization will destroy all sperms within the semen and eliminate the necessity for examining two consecutive specimens of semen for azoospermia after the operation. No local inflammatory response has been observed in the seminal vesicles or prostate of 81 consecutive patients in whom the method has been used.

\section{Introduction}

A disadvantage of vasectomy as a sterilizing procedure is the delay in the semen becoming azoospermic after the operation. A period of two to three months is usual, during which contraceptive precautions must be continued. By destroying the residual sperms with a non-irritant spermicidal solution at the time of division of the vasa it should be possible to overcome this disadvantage and render the semen sterile immediately.

von Friesen (1971) described a method in which a $1 / 1,000$ solution of ethacridine was used, which he claimed would dissolve the sperms in the vas deferens and seminal vesicles.

\section{Method}

Primary vasectomy for the purpose of contraception was carried out on 81 patients on an outpatient basis using local analgesia. Each vas was exteriorized through a separate scrotal incision $1 \mathrm{~cm}$ long and divided. The distal end of each vas was cannulated with a blunt-ended, $2.5 \mathrm{~cm}, 20 \mathrm{G}$ needle attached to a $5 \mathrm{ml}$ plastic syringe containing a sterile solution of $1 / 1,000$ euflavine; $2.5 \mathrm{ml}$ of the solution was injected slowly down each vas. Both proximal and distal ends of each vas were ligated separately by folding each end back on itself and tying each with 00 plain catgut. Plain catgut creates a greater fibrous reaction than the chromicized catgut, and it was felt that this reaction combined with the smooth and rounded contour presented by doubling each vas back on itself would reduce the risk of regeneration to

a minimum. The skin was closed with one suture of 00 plain catgut and a plastic spray dressing applied. Each patient was reviewed at two days and again three months after the procedure.

Examination of the semen was carried out two to 158 days after the operation and as frequently in each patient as he was prepared to allow. Specimens were collected by masturbation and examined immediately in the laboratory or, if preferred, during coitus and brought to the laboratory as quickly as possible thereafter. The interval between ejaculation and examination was one to 110 minutes. Altogether $88 \%$ of the specimens were examined within 30 minutes of ejaculation.

Semen examination was performed by the same technician in all cases. After centrifugation at 2,000 r.p.m. for five minutes a drop of the deposit was examined by light microscopy at $\times 40$. Ten fields were inspected and the number of sperms and the presence or absence of motility noted. Numbers of sperms were recorded as "many" (greater than $20,000,000 / \mathrm{mm}^{3}$ ),

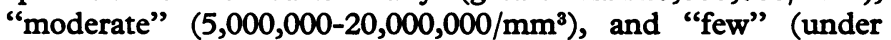
$5,000,000 / \mathrm{mm}^{3}$ ).

\section{Results}

In all 110 specimens of semen examined the sperms were nonmotile. Of these specimens 14 contained many sperms, 8 a moderate number of sperms, and 82 few sperms. Fifty-five of the specimens were collected within 10 days of the vasectomy, 40 between 11 and 50 days, and 10 between 51 and 158 days.

The interval between ejaculation and examination was 1-10 minutes for 54 specimens, 11-20 minutes for 24 specimens, 2130 minutes for 15 specimens, and 31-110 minutes for the remaining 12 specimens.

\section{Discussion}

Persistence of viable sperms in the semen after vasectomy is well. known and most surgeons insist on collecting two consecutive azoospermic specimens of semen some two to three months after the operation before accepting the subject as sterile. Many patients find this onerous, some distasteful, and a few ignore the advice. Sperms will retain their motility in ejaculated semen at room temperature for about 24 hours, but most laboratories will attach significance only to the percentage of motile sperms recorded in specimens examined within four hours of emission. All specimens in this series were examined within two hours of emission.

The acridine derivatives proflavine, acriflavine, aminacrine, ethacridine, and euflavine are slow-acting disinfectants. They 